\title{
Outcome following severe traumatic brain injury TBI correlates with serum S100B but not brain extracellular fluid S100B: An intracerebral microdialysis study*
}

\author{
Craig D. Winter ${ }^{1,2 \#}$, Geraldine F. Clough ${ }^{3}$, Ashley K. Pringle ${ }^{4}$, Martin K. Church ${ }^{3,5}$ \\ ${ }^{1}$ The Kenneth Jamieson Department of Neurosurgery, The Royal Brisbane and Women's Hospital, Brisbane, Australia \\ ${ }^{2}$ University of Queensland, Brisbane, Australia \\ ${ }^{3}$ Institute of Developmental Sciences, School of Medicine, University of Southampton, Southampton, UK \\ ${ }^{4}$ Institute of Clinical Neurosciences, School of Medicine, University of Southampton, Southampton, UK \\ ${ }^{5}$ Allergie-Centrum-Charité, Department of Dermatology and Allergy, Charité-Universitätsmedizin Berlin, Berlin, Germany \\ Email: " craigdw1@gmail.com
}

Received 14 February 2013; revised 16 March 2013; accepted 11 April 2013

Copyright (C) 2013 Craig D. Winter et al. This is an open access article distributed under the Creative Commons Attribution License, which permits unrestricted use, distribution, and reproduction in any medium, provided the original work is properly cited.

\begin{abstract}
S100B protein is released by astrocytes into the brain extracellular fluid following acute brain injury and elevated levels in CSF and serum have been shown to correlate with patient outcome following traumatic brain injury. A prospective study of brain extracellular fluid (ECF) and serum S100B levels in 12 patients with severe head injury (GCS $\leq 8$ ) was undertaken using intracerebral microdialysis to investigate whether a correlation with ECF S100B and outcome could be confirmed. Patient outcomes were assessed at 6 months using the Glasgow Outcome Scale (GOS) and divided into two outcome groups: group $A, 8$ survivors with either a good recovery or moderate disability (GOS scores of 4 or 5); and group B, 4 patients who died (GOS 1). Peak serum levels of S100B were significantly greater in group $B$ (mean 6.03 $\mathrm{ng} / \mathrm{ml})$ compared with group $A$ (mean $0.73 \mathrm{ng} / \mathrm{ml})(P$ $=0.009)$. Group A had a mean peak S100B in the extracellular compartment of $186 \mathrm{ng} / \mathrm{ml}$ compared to $150 \mathrm{ng} / \mathrm{ml}$ in group B. There was no significant difference between the mean peak brain ECF S100B concentrations for the 2 outcome groups $(P=\mathbf{0 . 9 3 2})$. We confirm that intracerebral microdialysis can be used to sample S100B concentrations from brain extracellular fluid and our results suggest that the ECF S100B levels were variable and that there was no significant difference between the good outcome and poor outcome groups. In contrast, the serum levels of S100B of patients with a poor outcome were significantly higher than those with a good outcome.
\end{abstract}

\footnotetext{
"Author disclosure statement: no competing financial interests exist.

${ }^{\#}$ Corresponding author.
}

Keywords: Microdialysis; S100B; Traumatic Brain Injury

\section{INTRODUCTION}

Traumatic brain injury (TBI) is the leading cause of death and disability among young adults worldwide $[1,2]$. Accurate prediction of patient outcome following severe TBI using a peripheral biomarker may add to current prognostication. Such a marker could also be used to assess standard treatment regimens and be used as a potential surrogate marker in head injury trials to establish the efficacy of novel neuroprotective drugs. S100B is a calcium binding protein, predominantly found in glial and Schwann cells $[3,4]$, which has potential as a biomarker in TBI patients. Cerebrospinal fluid (CSF) and serum levels of S100B have been extensively investigated as markers of the severity of brain injury after trauma and stroke. Serum S100B levels correlate with patient outcome after severe TBI [5-7] leading to the supposition that the increased level primarily reflects the extent of cellular damage in the brain. However, the effects of trauma-induced blood-brain barrier (BBB) dysfunction, increased S100B expression secondary to brain reparative processes and extracranial sources in the multitrauma patient make any definitive conclusions regarding the ability of serum S100B to reflect brain injury alone problematic. Accuracy in understanding S100B dynamics, its release and its diffusion into various fluid compartments following acute brain injury would potentially improve upon the sensitivity and validity of its interpretation. We have used intracerebral microdialysis to sample the brain extracellular fluid (ECF), enabling us to 
compare S100B levels in the brain with intravascular compartments and to comment on ECF and serum S100B correlation with patient outcome.

\section{MATERIALS AND METHODS}

\subsection{Patients}

Twelve intubated and artificially ventilated severely head injured patients (Glasgow Coma Score or GCS $\leq 8$ ) were admitted to the Neurosurgical Intensive Care Unit and recruited onto the study following assent by the next of kin. Clinical details such as mechanism of injury, initial GCS, computed tomography (CT) findings, other system injuries, age, presence of hypoxia or hypotension and systemic sepsis were documented for each patient. The patient outcomes were assessed at 6 months using the Glasgow Outcome Scale (GOS) where a $5=$ good recovery, $4=$ moderate disability, $3=$ severe disability, $2=$ vegetative state and $1=$ death. The study was granted ethics approval by the Local Regional Ethics Committee and performed in accordance with the Declaration of Helsinki. Patients under the age of 16 were excluded.

\subsection{Microdialysis Sampling}

The microdialysis probes were constructed by Microbiotech, Sweden using an Asahi-Plasmaseparator polyethylene polymer tubular membrane of internal diameter $330 \mu \mathrm{m}$ and wall thickness $50 \mu \mathrm{m}$ (Ashai Plasmaseparator, Diamed Medizitechnik, Cologne, Germany), with an effective dialysis length of $12-15 \mathrm{~mm}$ and a molecular mass cut-off of $3000 \mathrm{kDa}$. The probes were inserted distant to sites of focal pathology (ie contusions) such that the S100B levels in the dialysates would reflect glial cell release secondary to the diffuse element of brain damage associated with the severe TBI. The flow rate was set at 1 $\mu \mathrm{L} / \mathrm{min}$ and the infusate was sterile normal saline $(0.9 \%$ $\mathrm{NaCl}$, Maco Pharma, London, UK). Dialysate was collected over a 4 hour period for up to 5 days following probe insertion and stored at $-80^{\circ} \mathrm{C}$ for later analysis of S100B. This novel method (large pore size and high flow rate) was initially developed as a technique for the in vivo sampling of brain interstitial fluid to allow the extraction of macromolecules, such as cytokines, from severely head injured patients $[8,9]$. Daily venous blood samples were also taken and the sera stored at $-80^{\circ} \mathrm{C}$. S100B protein was assayed using a Sangtec ${ }^{\circledR} 100$ IRMA (AB Sangtec Medical, Bromma, Sweden) S100B assay with a lower limit of detection of $0.5 \mathrm{ng} / \mathrm{ml}$.

\subsection{Statistical Analysis}

The data could not be assumed to be normally distributed, so statistical differences were tested using a Mann Witney $\mathrm{U}$ test for non-parametric data. A probability of $P<$
0.05 was taken as statistically significant.

\section{RESULTS}

Admission CT scans revealed various intracranial injuries, including diffuse axonal injury, acute subdural, extradural and intracerebral haematomas and contusions, with some individuals suffering a combination of injuries. Mechanisms of injury included falls, road traffic accidents, assaults, horse riding and a light aircraft accident. Standard aggressive head injury management, including sedation, haematoma evacuation, intracranial pressure monitoring, neuromuscular paralysis and administration of mannitol was undertaken for each patient. The patients' age ranged from 21 to 77 . There were no complications attributable to probe implantation in any of the patients. The patients were divided into two outcome groups, the 8 survivors with either a good recovery or moderate disability (group A) and the 4 patients who died (group B or non-survivors) whilst in intensive care. There were no differences in other injuries or adverse systemic events between the two groups. The peak levels of S100B in the brain dialysate of patients with a good outcome (group A) ranged from $10-600 \mathrm{ng} / \mathrm{ml}$ (mean $\pm \mathrm{SEM}, 186 \pm 74 \mathrm{ng} / \mathrm{ml}$ ) while those of patients with a poor outcome (group B) ranged from $6-295 \mathrm{ng} / \mathrm{ml}($ mean $\pm \mathrm{SEM}, 150 \pm 68 \mathrm{ng} / \mathrm{ml})$ (Figure 1). There was no statistically significant difference between these levels $(P=0.932)$. The peak S100B serum concentrations of two patients in Group A were 1.65 and $1.15 \mathrm{ng} / \mathrm{ml}$ while the concentrations in the remaining six patients were below the lower detection limit of the assay of $0.5 \mathrm{ng} / \mathrm{ml}$. For statistical purposes if we designate $0.5 \mathrm{ng} / \mathrm{ml}$ as the value for each of these six patients we can say that the peak serum S100B values ranged from $0.5-1.65 \mathrm{ng} / \mathrm{ml}$ (mean $\pm \mathrm{SEM}, 0.73 \pm 0.12$ $\mathrm{ng} / \mathrm{ml}$ ) in group A and from $2.25-9.20 \mathrm{ng} / \mathrm{ml}$ (mean \pm
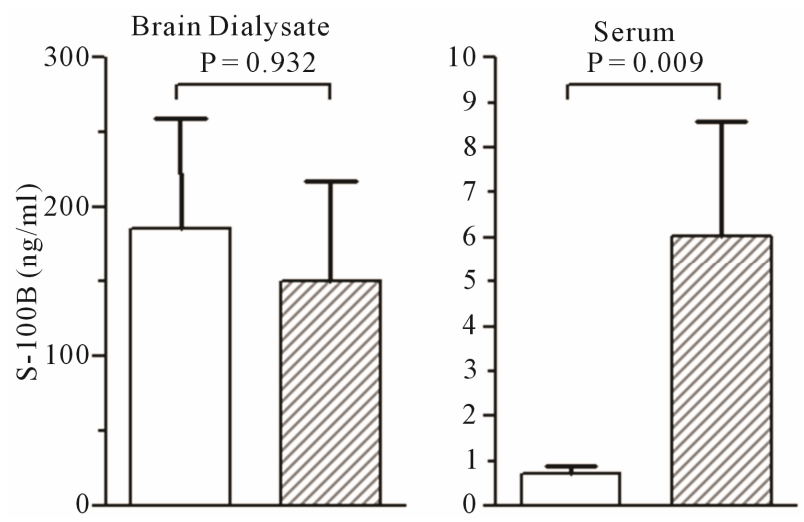

Figure 1. Bar charts showing mean \pm SEM S100B level in brain dialysate and serum. Group A (survivors) is represented by the open bars and group B (non-survivors) is represented by the hatched bars. 
SEM, $6.03 \pm 2.5 \mathrm{ng} / \mathrm{ml}$ ) in group B. Peak serum levels of S100B were significantly greater in group B compared with group A $(P=0.009)$ (Figure 1).

\section{DISCUSSION}

We report serum and brain extracellular fluid S100B levels in 12 severely head injured patients. The patients were divided into two outcome groups, 8 survivors with either a good recovery or moderate disability (group A) and 4 patients who died (group B). The mean peak serum S100B concentration in Group B was $6.03 \pm 2.5 \mathrm{ng} / \mathrm{ml}$ compared to $0.73 \pm 0.12 \mathrm{ng} / \mathrm{ml}$ in group A i.e., signifycantly greater $(P=0.009)$. These results are elevated compared to historical controls. Median baseline plasma $\mathrm{S} 100 \mathrm{~B}$ values have been documented as $0.046 \mathrm{ng} / \mathrm{ml}$ [10] with a normal serum S100B range of 0.02 to $0.15 \mathrm{ng} / \mathrm{ml}$ $[11,12]$. Our serum S100B results are also consistent with S100B data in head injured patients. A comparable range $(0.02-9.6 \mathrm{ng} / \mathrm{ml}$, median $1.59+/-2.41)$ has been reported in a prospective study of 60 head injured patients [13]. The statistically significant increased mean peak serum S100B in our poor outcome group, compared to the good outcome group, is consistent with the body of literature which confirms a strong correlation between peripheral S100B and patient outcome following severe TBI [14-19]. The accuracy of the association between serum S100B and patient outcome is not without controversy given well known extracranial sources of S100B, blood-brain barrier dysfunction and other clinical conditions that have been associated with elevated levels.

Though a normal serum S100B level may reliably indicate the absence of significant CNS damage [20] with $0.21 \mathrm{ng} / \mathrm{ml}$ suggested as a cut-off for predicting primary brain injury and/ or severe disability following minor TBI [21], the validity of peripheral S100B as an indicator of both the severity of initial brain injury and the resultant patient outcome in the multi-trauma setting has been questioned. Studies have confirmed elevated S100B levels in trauma patients without head injury in keeping with well-established extracranial sources (adipocytes and muscle cells) of S100B [22-24]. An elevated serum S100B level occurring at least once in 46 non-trauma critically ill patients without any apparent brain damage (median $0.31 \mathrm{ng} / \mathrm{ml}$, range 0.04 - 18) has also been reported [25]. Other clinical scenarios have further confounded the specificity of S100B as a measure of trauma induced brain injury [26] with increased levels noted in patients with obstructive sleep apnoea [27], dilated cardiomyopathy [28], carbon monoxide poisoning [29] and be associated with lesion volume, clinical status and functional outcome in a number of studies investigating stroke [30-32]. Elevated levels following certain sports such as soccer, boxing, swimming and running have also been reported [33-35]. However, other authors have ana- lysed multi-trauma patients and concluded that regardless of the presence of systemic injuries, serum S100B remains a valid predictor of the severity of brain injury [18,36].

The intravascular S100B level will ultimately depend on several processes such as TBI induced astrocytic release, its passage through a damaged BBB and extracranial sources. Studies have also suggested that, in addition to the elevation of S100B secondary to direct brain parenchymal trauma (a passive release), TBI stimulated astrocytes may actively express $\mathrm{S} 100 \mathrm{~B}$ as part of a reparative process [37]. The extent of BBB dysfunction has been suggested as playing a prominent part in the interpretation of the level of S100B in trauma patients with some authors suggesting serum S100B is a measure of $\mathrm{BBB}$ dysfunction alone. That $\mathrm{BBB}$ disruption occurs following head injury is well recognised [38-40]. A method used to quantify the extent of damage is the cerebrospinal fluid (CSF)-serum albumin quotient (QA) which is considered by some authors to be a "gold standard" measure of blood-CSF barrier function (presumed to be similar to BBB) $[41,42]$. To add support that serum $\mathrm{S} 100 \mathrm{~B}$ may be used as a measure of BBB dysfunction alone, good correlation between QA and serum S100B levels have been confirmed following traumatic brain injury [43]. Though in opposition to this, CSF and serum $\mathrm{S} 100 \mathrm{~B}$ with QA was measured in TBI patients and the authors concluded that serum S100B levels were not influenced to a great degree by $\mathrm{BBB}$ integrity, and so may reflect true cellular damage [44]. Controversy therefore continues regarding whether peripheral S100B reflects predominantly the primary parenchymal damage or BBB dysfunction, though in all probability it represents a combination of both.

We report both brain S100B ECF and serum values in 12 severe TBI patients, seeking to potentially add clarification to the dynamics of S100B in acute brain injury, and to comment on possible ECF correlation with patient outcome. Although elevated ECF S100 levels using microdialysis in the infarct core and penumbral region around a stroke has been performed [45], to our knowledge only one other study has evaluated ECF S100B in the trauma setting [46]. The authors confirmed levels up to $75 \mathrm{ng} / \mathrm{ml}$ in a single patient with severe TBI, though serum levels were not commented on. The peak levels of both serum and ECF in our study occurred within the first 48 hours following injury in keeping with other authors confirming early S100B peaks in serum and CSF [14].

The peak levels of S100B in the brain dialysate of patients with a good outcome (group A) ranged from 10 $600 \mathrm{ng} / \mathrm{ml}($ mean $\pm \mathrm{SEM}, 186 \pm 74 \mathrm{ng} / \mathrm{ml})$ while those of patients with a poor outcome (group B) ranged from 6 $295 \mathrm{ng} / \mathrm{ml}$ (mean $\pm \mathrm{SEM}, 150 \pm 68 \mathrm{ng} / \mathrm{ml}$ ) (Figure 1). 
There was no statistically significant difference between these levels $(P=0.932)$. These values are in fact likely to be lower than the true extracellular concentrations given the constraints of microdialysis. First, the recovery efficiencies in TBI patients using our microdialysis membrane for interleukin- 6 and nerve growth factor, molecules of similar molecular weights were $45 \%$ and $22 \%$ respectively [8]. Second, continued tissue dialysis depletes dialyzable molecules in the immediate surrounding tissue leading to a further underestimation of their concentration [47].

Following acute brain injury S100B is released into the ECF by glial cells (passively or actively) and diffuses into the CSF (with passage to blood as the CSF is absorbed) or directly into the vascular compartment via a disrupted BBB. Those CSF S100B concentrations reflect the ECF S100B level is assumed to be the case, given that both compartments communicate via non-barrier spaces [48]. Our S100B ECF levels are considerably higher than the majority of previously reported CSF S100B levels in severe TBI patients, though the latter have been variably reported. Mean peak CSF S100B values of $819 \pm 78 \mathrm{pg} / \mathrm{ml}, 200$-fold less than our ECF values $(150-180 \mathrm{ng} / \mathrm{ml})$ [49], $11.7 \mathrm{ng} / \mathrm{ml}$ (100-fold difference) [14], $7.34 \pm 4.87 \mathrm{ng} / \mathrm{ml}$ [50], $64.98+/-272.39$ $\mathrm{ng} / \mathrm{ml}$ [51] and $23-1058 \mathrm{ng} / \mathrm{ml}$ (median $36 \mathrm{ng} / \mathrm{ml}$, i.e. approximating our ECF concentrations) [44] have all been reported.

Notwithstanding the controversy of extracranial S100B sources and BBB dysfunction described above, it has been assumed that the predictive value of serum S100B and the positive correlation of serum S100B levels with patient outcome relate in the main to the degree of brain parenchymal injury and S100B release into the ECF. We however cannot confirm a correlation between ECF and patient outcome though our serum results in the same patients did show a statistically significant correlation. Similarly, the literature has been unable to confirm a consistent correlation between CSF S100B and outcome, with some authors confirming that the severe TBI patients with higher CSF S100B concentrations had higher acute mortality and worse outcome $[14,50]$ though others were unable to confirm the same [44,51].

We did expect that there would be correlation between ECF and serum S100B levels and therefore between the ECF level and patient outcome, but this was not the case. Our results primarily reveal that the serum S100B level correlates with patient outcome and that the ECF S100B level does not. The increased serum S100B levels in the poor outcome patients could potentially reflect a greater functional disturbance of the BBB throughout the brain resulting in more S100B leaking from the extracellular compartment into the intravascular space (directly or via the CSF). That a patient with a more severely disrupted
BBB throughout their brain has a worse outcome would not be surprising, given the potential for increased vasogenic oedema, intracranial hypertension, seizure activity and on a molecular level alteration of extracellular ion composition, accumulation of toxic substances (eg excessive glutamate) and extravasation of plasma proteins, all of which may alter interneuronal connectivity and neuronal function. The ratio of ECF to serum S100B could potentially serve as a future estimation of BBB dysfunction.

Our study has limitations inherent to all intracerebral dialysis studies, namely that the substances measured in the dialysate simply reflect parenchymal damage seconddary to catheter insertion. Although microdialysis has been shown to produce a degree of tissue injury [52] we are optimistic that the trauma associated with probe implantation may not cause significant artefact in the ECF S100B results for two reasons. The maximum volume of irreversibly damaged brain tissue adjacent to a microdialysis probe is in the order of $1.5 \mathrm{~mm}^{3}[53,54]$ whereas the catchment volume is approximately 100 times large [55]. Adenosine, a known biochemical marker of tissue damage, has been found to be low in the area immediately surrounding a microdialysis catheter in subcutaneous adipose tissues [56].

Our choice of catheter position is open to criticism in that it could be argued that they could have been placed into non-pathological brain. Contused brain consists of disruption to small blood vessels, microhaemorrhages, leakage into the ECF, neuronal and glial injury, BBB disruption, vasogenic oedema and penumbral damage. We therefore hypothesised that measuring ECF S100B in contused brain or peri-contusional areas may have yielded variable results dependent on the extent of focal damage and the exact location of the catheter. This could potentially reduce the validity of the dialysate levels in terms of attempting to clarify S100B dynamics. The dialysates were sampled from the frontal lobe (approximately $2 \mathrm{~cm}$ from the cortical surface) of the brain, distant from sites of contusions, such that the S100B levels might reflect glial cell release secondary to the diffuse element of brain damage known to be associated with severe TBI. That our ECF S100B levels are of the same order, and tend to be even higher, than the dialysates from 'the edge of a contusion' [46] would also support that we were in damaged brain. Our ECF levels are significantly higher than CSF S100B values in previous TBI studies, suggesting again that the dialysis probes were placed into pathological brain. Furthermore, it seems counter-intuitive to suggest that in those patients who died from severe TBI that there was not an element of global damage. We also note that higher CSF S100B values have been previously documented in diffuse injuries compared to focal injuries [44]. 
Use of an external ventricular drain (EVD) was not standard practice at the time of the study and so we could not gain CSF S100B concentrations for all the patients. The patient numbers in our study is small $(\mathrm{n}=12)$ which reduces the validity of our conclusions. Future work would welcome this addition, adding not only CSF S100B values but the ability to compare blood-CSF barrier function (QA) with BBB as estimated by ECF and serum S100B concentration ratios. Although there were no significant differences between systemic injuries between the two groups, extracranial sources may have influenced the S100B serum level but we do not feel would have significantly altered the ECF values. Accuracy in understanding the time course of $\mathrm{S} 100 \mathrm{~B}$ release and its diffusion into various fluid compartments following acute brain injury could improve upon the sensitivity and validity of interpreting the level at a specific time point. Furthermore, ECF S100B could potentially be part of microdialysis multimodal monitoring in the intensive care setting, in order to monitor secondary brain injury and the efficacy of novel therapeutic neuroprotective drugs.

\section{CONCLUSION}

We confirm that intracerebral microdialysis can be used to sample S100B concentrations from brain ECF in severely head injured patients. Our results suggest that the S100B levels recovered from the frontal lobe of the brain of patients with severe TBI were variable and that there was no significant difference between those with a good clinical outcome and those with a poor outcome. In contrast, the serum levels of S100B of patients with a poor outcome were significantly higher than those with a good outcome, in keeping with the majority of peripheral S100B literature related to head injury.

\section{REFERENCES}

[1] Jennett, B. (1996) Epidemiology of head injury. Journal of Neurology, Neurosurgery \& Psychiatry, 60, 362-369. doi:10.1136/jnnp.60.4.362

[2] Steyerberg, E.W., Mushkudiani, N., Perel, P., Butcher, I., Lu, J., McHugh, G.S., Murray, G.D., Marmarou, A., Roberts, I., Habbema, J.D. and Maas, A.I. (2008) Predicting outcome after traumatic brain injury: Development and international validation of prognostic scores based on admission characteristics. PLOS Medicine, 5, Article ID: e165; Discussion e165, doi:10.1371/journal.pmed.0050165

[3] Barger, S.W. and Van Eldik, L.J. ()1992 S100 beta stimulates calcium fluxes in glial and neuronal cells. The Journal of Biological Chemistry, 267, 9689-9694.

[4] Beaudeux, J., Dequen, L. and Foglietti, M. (1999) Pathophysiologic aspects of S100 beta protein: A new biological marker of brain pathology. Annales de Biologie Cli- nique (Paris), 57, 261-272.

[5] Raabe, A., Grolms, C., Keller, M., Dohnert, J., Sorge, O. and Seifert, V. (1998) Correlation of computed tomogram- phy findings and serum brain damage markers following severe head injury. Acta Neurochirurgica (Wien), 140, 787-791. doi: $10.1007 / \mathrm{s} 007010050180$

[6] Nylen, K., Ost, M., Csajbok, L.Z., Nilsson, I., Hall, C., Blennow, K., Nellgard, B. and Rosengren, L. (2008) Serum levels of S100B, S100A and S100BB are all related to outcome after severe traumatic brain injury. Acta Neurochirurgica (Wien), 150, 221-227. Discussion 227. doi:10.1007/s00701-007-1489-2

[7] Rainey, T., Lesko, M., Sacho, R., Lecky, F. and Childs, C. (2009) Predicting outcome after severe traumatic brain injury using the serum S100B biomarker: Results using a single (24h) time-point. Resuscitation, 80, 341-345. doi:10.1016/j.resuscitation.2008.11.021

[8] Winter, C.D., Iannotti, F., Pringle, A.K., Trikkas, C., Clough, G.F. and Church, M.K. (2002) A microdialysis method for the recovery of IL-1beta, IL-6 and nerve growth factor from human brain in vivo. Journal of Neuroscience Methods, 119, 45-50. doi:10.1016/S0165-0270(02)00153-X

[9] Winter, C.D., Pringle, A., Clough, G.F. and Church, M.K. (2004) Raised parenchymal interleukin-6 levels correlate with improved outcome after traumatic brain injury. Brain, 127, 315-320. doi:10.1093/brain/awh039

[10] Alber, B., Hein, R., Garbe, C., Caroli, U. and Luppa, P.B. (2005) Multicenter evaluation of the analytical and clinical performance of the Elecsys S100 immunoassay in patients with malignant melanoma. Clinical Chemistry and Laboratory Medicine, 43, 557-563. doi:10.1515/CCLM.2005.097

[11] Lara, D.R., Gama, C.S., Belmonte-de-Abreu, P., Portela, L.V., Goncalves, C.A., Fonseca, M., Hauck, S. and Souza, D.O. (2001) Increased serum S100B protein in schizophrenia: A study in medication-free patients. Journal of Psychiatric Research, 35, 11-14. doi:10.1016/S0022-3956(01)00003-6

[12] Portela, L.V., Tort, A.B., Schaf, D.V., Ribeiro, L., Nora, D.B., Walz, R., Rotta, L.N., Silva, C.T., Busnello, J.V., Kapczinski, F., Goncalves, C.A. and Souza, D.O. (2002) The serum S100B concentration is age dependent. Clinical Chemistry, 48, 950-952.

[13] Wiesmann, M., Steinmeier, E., Magerkurth, O., Linn, J., Gottmann, D. and Missler, U. (2010) Outcome prediction in traumatic brain injury: Comparison of neurological status, CT findings and blood levels of S100B and GFAP. Acta Neurologica Scandinavica, 121, No. 3, 2010, pp. 178185. doi:10.1111/j.1600-0404.2009.01196.x

[14] Goyal, A, Carter, M., Niyonkuru, C., Fabio, A., Amin, K., Berger, R.P. and Wagner, A.K. (2012) S100B as a prognostic biomarker in outcome prediction for patients with severe TBI. Journal of Neurotrauma. doi:10.1089/neu.2012.2579

[15] Rodriguez-Rodriguez, A., Egea-Guerrero, J.J., Leon-Justel, A., Cordillo-Escobar, E., Revuelto-Rey, J., Vilches-Arenas, A., Carrillo-Vico, A., Dominguez-Roldan, J.M., MurilloCabezas, F. and Guerrero, J.M. (2012) Role of S100B 
protein in urine and serum as an early predictor of mortality after severe traumatic brain injury in adults. Clinica Chimica Acta, 414, 228-233. doi:10.1016/i.cca.2012.09.025

[16] Bouvier, D., Eisenmann, N., Gillart, T., Bonneau, J., Guelon, D., Schoeffler, P. and Sapin, V. (2012) Jugular venous and arterial concentrations of serum S100B protein in patients with severe head injury. Annales de Biologie Clinique (Paris), 70,269-275.

[17] Thelin, E.P., Johannesson, L.K., Nelson, D.W. and Bellander, B.M. (2013) S100B is an important predictor in traumatic brain injury. Journal of Neurotrauma. doi:10.1089/neu.2012.2553

[18] da Rocha, A.B., Schneider, R.F., de Freitas, G.R., Andre, C., Grivich I., Zanoni, C., Fossa, A., Gehrke, J.T., Pereira, Jotz G., Kaufmann, M., Simon, D. and Regner, A. (2006) Role of serum S100B as a predictive marker of fatal outcome following isolated severe head injury or multitrauma in males. Clinical Chemistry and Laboratory Medicine, 44, 1234-1242. doi:10.1515/CCLM.2006.218

[19] Dimopolou, I., Korfias, S., Dafni, U., Anthi, A., Psachoulia, C., Julien, G., Sakas, D.E. and Roussos, C. (2003) Protein S100B serum levels in trauma-induced brain death. Neurology, 60, 947-951. doi:10.1212/01.WNL.0000049931.77887.7F

[20] Bloomfield, S.M., McKinney, J., Smith, L. and Brisman, J. (2007) Reliability of S100B in predicting severity of central nervous system injury. Neurocritical Care, 6, 121138. doi:10.1007/s12028-007-0008-X

[21] Mussack, T., Biberthaler, P., Kanz, K.G., Heckl, U., Gruber, R., Linsenmaier, U., Mutscler, W. and Jochum, M. (2002) Immediate S100B and Neuron-Specific Enolase plasma measurements for rapid evaluation of primary brain damage in alcohol-intoxicated, minor head-injured patients. Shock, 18, 395-400. doi:10.1097/00024382-200211000-00002

[22] Anderson, R.E., Hansson, L.O., Nilsson, O., Dijlai-Merzoug, R. and Settergren, G. (2001) High serum S100B levels for trauma patients without head injuries. Neurosurgery, $\mathbf{4 8}$, 1255-1258.

[23] Savola, O., Pyhtinen, J., Leino, T.K., Siitonen, S., Niemela, O. and Hillbom, M. (2004) Effects of head and extracranial injuries on serum protein S100B levels in trauma patients. Trauma and Acute Care Surgery, 56, 1229-1234. doi:10.1097/01.TA.0000096644.08735.72

[24] Cotton, B.A., Girard, T.D. and Ely, E.W. (2007) Increased levels of serum S100B protein in critically ill patients without brain injury. Shock, 27, 338. doi:10.1097/01.shk.0000239756.59841.29

[25] Routsi, C., Stamataki, E., Nanas, S., Psachoulia, C., Stathpoulos, A., Koroneos, A., Zervon, M., Julian, G. and Roussos, C. (2006) Increased levels of serum S100B protein in critically ill patients without brain injury. Shock, 26, 20-24. doi:10.1097/01.shk.0000209546.06801.d7

[26] Yardan, T., Erenler, A.K., Baydin, A., Aydin, K. and Cokluk, C. (2011) Usefulness of S100B protein in neurological disorders. Journal of Pakistan Medical Association, 61, 276-281.

[27] Braga, C.W., Martinez, D., Wofchuk, S., Portela, L.V. and Souza, D.O. (2006) S100B and NSE serum levels in obstructive sleep apnea syndrome. Sleep Medicine, 7, 431435. doi:10.1016/j.sleep.2005.12.012

[28] Mazzini, G.S., Schaf, D.V., Vinade, E.R., Horowitz, E., Bruch, R.S., Brunm, L.M., Goncalves, C.A., Bacal, F., Souza, D.O., Portela, L.V. and Bordignon, S. (2007) Increased S100B serum levels in dilated cardiomyopathy patients. Journal of Cardiac Failure, 13, 850-854. doi:10.1016/j.cardfail.2007.07.009

[29] Yardan, T., Cevik, Y., Donderici, O., Kavalci, C., Yilmaz, F.M., Vural, K., Yuzbasioglu, Y., Gunaydin, Y.K. and Sezer, A.A. (2009) Elevated serum S100B protein and neuron-specific enolase levels in carbon monoxide poisoning. The American Journal of Emergency Medicine, 27, 838-842. doi:10.1016/j.ajem.2008.04.016

[30] Buttner, T., Weyers, S., Postert, T., Sprengelmeyer, R. and Khun, W. (1997) S100 protein: Serum marker of focal brain damage after ischaemic territorial MCA infarction. Stroke, 28, 1961-1965. doi:10.1161/01.STR.28.10.1961

[31] Fassbender, K., Schmidt, R., Schreiner, A., Fatar, M., Muhlhauser, F. and Hennerici, M.D. (1997) Leakage of brain-originated proteins in peripheral blood: Temporal profile and diagnostic value in early ischaemic stroke. Journal of the Neurological Sciences, 148, 101-105. doi:10.1016/S0022-510X(96)05351-8

[32] Herrmann, M., Vos, P., Wunderlich, M.T., de Bruijn, C.H. and Lamers, K.J. (2000) Release of glial tissue-specific protein after acute stroke: A comparative analysis of serum concentrations of protein S100B and glial fibrillary acidic protein. Stroke, 31, 2670-2677. doi:10.1161/01.STR.31.11.2670

[33] Straume-Naesheim, T.M., Anderson, T.E., Jochum, M., Dvorak, J. and Bahr, R. (2008) Minor head trauma in soccer and serum levels of S100B. Neurosurgery, 62, 1297-1305. doi:10.1227/01.neu.0000333301.34189.3d

[34] Otto M., Holthusen S., Bahn E., Sohnchen N., Wiltfang J., Geese R., Fischer A. and Reimers C.D. (2000) Boxing and running lead to a rise in serum levels of S100B protein. International Journal of Sports Medicine, 21, 551555. doi:10.1055/s-2000-8480

[35] Dietrich M.O., Tort A.B., Schaf, D.V., Farina M., Goncalves C.A., Souza D.O. andPortela L.V. (2003) Increase in serum S100B protein level after a swimming race. Canadian Journal of Applied Physiology, 28, 710-716. doi:10.1139/h03-054

[36] Gonzclez-Mao, M.C., Reparaz-Andrade, A., Del CampoPerez, V., Alvarez-Garcia, E., Vara-Perez, C. and AndradeOlivie, M.A. (2011) Model predicting survival/exitus after traumatic brain injury: Biomarker S100B 24h. Clinical Laboratary, 57, 587-597.

[37] Kleindienst, A. and Bullock, R.R. (2006) A critical analysis of the role of the neurotrophic protein $\mathrm{S} 100 \mathrm{~B}$ in acute brain injury. Journal of Neurotrauma, 23, 1185-1200. doi:10.1089/neu.2006.23.1185

[38] Korn, A., Golan, H., Melamed, I., Pascual-Marqui, R. and Friedman, A. (2005) Focal cortical dysfunction and bloodbrain barrier disruption in patients with post-concussion syndrome. Journal of Clinical Neuro-Physiology, 22, 1-9. 
doi:10.1097/01.WNP.0000150973.24324.A7

[39] Tomkins, O., Shelef, I., Kaizerman, I., Eliushin, A., Misk, Z.A., Gidon, M., Cohen,A., Zumsteg, D. and Friedman, A. (2008) Blood-brain barrier disruption in post-traumatic epilepsy. Journal of Neurosurgery \& Psychiatry with Practical Neurology, 79, 774-777.

doi:10.1136/jnnp.2007.126425

[40] Shlosberg, D., Benifla, M., Kaufer. D. and Friedman, A. (2010) Blood-brain barrier breakdown as a therapeutic target in traumatic brain injury. Nature Reviews. Neurology, 6, 393-403. doi:10.1038/nrneurol.2010.74

[41] Andersson, M., Alvarez-Cermeno, J., Bernardi, G., Cogato, I., Fredman, P., Frederiksen, J., Fredrikson, S., Gallo, P., Grimaldi, L.M., Gronning, M., Keir, G., Lamers, K., Link, H., Magalhaes, A., Massaro, A.R., Ohman, S., Reiber, H., Ronnback, L., Schluep, M., Schuller, E., Sindic, C.J.M., Thompson, E.J., Trojano, M. and Wurster, U. (1994) Cerebrospinal fluid in the diagnosis of multiple sclerosis: A consensus report. Journal of Neurology, Neurosurgery \& Psychiatry with Practical Neurology, 57, 897-902.doi:10.1136/jnnp.57.8.897

[42] Reiber, H. and Peter, J.B. (2001) Cerebrospinal fluid analysis: Disease-related data patterns and evaluation programs. Journal of Neurological Sciences, 184, 101-122.

[43] Blyth, B.J., Farhavar, A., Gee, C., Hawthorn, B., He, H., Nayak, A., Stocklein, V. and Bazarian, J.J. (2009) Validation of serum markers for blood-brain barrier disruption in traumatic brain injury. Journal of Neurotrauma, 26, 1497-1507. doi:10.1089/neu.2008.0738

[44] Bellander, B.M., Olafsson, I.H., Ghatan, P.H., Skejo, B.H.P., Hansson, L.O., Wanecek, M. and Svensson, M.A. (2011) Secondary insults following traumatic brain injury enhance complement activation in the human brain and release of the tissue damage marker S100B. Acta Neurochirurgica, 153, 90-100. doi:10.1007/s00701-010-0737-Z

[45] Dayon, L., Turck, N., Garcia-Berrocoso, T., Walter, N., Burkhard, P.R., Vilalta, A., Sahuquillo, J., Montaner, J. and Sanchez, J.C. (2011) Brain extracellular fluid protein changes in acute stroke patients. Journal of Proteome Research, 10, 1043-1051. doi:10.1021/pr101123t

[46] Sen, J., Belli, A., Petzold, A., Russo, S., Keir, G., Thompson, E.J., Smith, M. and Kitchen, N. (2005) Extracellular fluid S100B in the injured brain: A future surrogate marker of acute brain injury? Acta Neurochirurgica, 147, 897-900. doi:10.1007/s00701-005-0526-2
[47] Clough, G.F., Boutsiouki, P., Church, M.K. and Michel, C.C. (2002) Effects of blood flow on the in vivo recovery of a small diffusible molecule by microdialysis in human skin. The Journal of Pharmacology and Experimental Therapeutics, 302, 681-686.doi:10.1124/jpet.102.035634

[48] Cserr, H.F. (1971) Physiology of the choroid plexus. Physiological Reviews, 51, 273-311.

[49] Kirchhoff, C., Buhmann, S., Braunstein, V., Leidel, B.A., Vogel, T., Kreimeier, U., Mutschler, W. and Biber- thaler, P. (2008) Cerebrospinal S100-B: A potential marker for progressive intracranial haemorrhage in patients with severe traumatic brain injury. European Journal of Medical Research, 13, 511-516.

[50] Bohmer, A.E., Oses, J.P., Schmidt, A.P., Peron, C.S., Krebs, C.L., Oppitz, P.P., D’Avila, T.T., Souza, D.O., Portela, L.V. and Stefani, M.A. (2011) Neuro-specific enolase, S100B, and glial fibrillary acidic protein levels as outcome predictors in patients with severe traumatic brain injury. Neurosurgery, 68, 1624-1630. doi:10.1227/NEU.0b013e318214a81f

[51] Kliendienst, A., Schmidt, C., Parsch, H., Emtmann, I., Xu, Y. and Buchfelder, M. (2010) The passage of S100B from brain to blood is not specifically related to blood-brain barrier intregrity. Cardiovascular Psychiatry and Neurology, 2010, Article ID: 801295, 8 Pages. doi: $10.1155 / 2010 / 801295$

[52] Stenken, J.A., Church, M.K., Gill, C.A. and Clough, G.F. (2010) How minimally invasive is microdialysis sampling? A cautionary note for cytokine collection in human skin and other clinical studies. AAPS Journals, 12, 73-78. doi:10.1208/s12248-009-9163-7

[53] Benveniste, H. and Diemer, N.H. (1987) Cellular reactions to implantation of a microdialysis tube in the rat hippocampus. Acta Neuropathologica, 74, 234-238. doi:10.1007/BF00688186

[54] Landolt, H., Langemann, H. and Alessandri, B. (1996) A concept for the introduction of cerebral microdialysis in neurointensive care. Acta Neurochirurgica, 67, S31-S36.

[55] Benveniste, H. and Huttemeier, P.C. (1990) Microdialysis - Theory and application. Progress in Neurobiology, 35, 195-215. doi:10.1016/0301-0082(90)90027-E

[56] Lonnroth, P. and Smith, U. (1990) Microdialysis-A novel technique for clinical investigations. Journal of Internal Medicine, 227, 295-300. doi:10.1111/j.1365-2796.1990.tb00163.x 